\title{
Gaseous elemental mercury concentration in atmosphere at urban and remote sites in China
}

\author{
WANG Zhang-wei ${ }^{1}$, CHEN Zuo-shuai ${ }^{1}$, DUAN Ning ${ }^{2}$, ZHANG Xiao-shan ${ }^{1, *}$ \\ 1. Research Center for Eco-Environmental Sciences, Chinese Academy of Sciences, Beijing 100085, China. \\ E-mail: wangzhw@rcees.ac.cn \\ 2. Chinese Research Academy of Environmental Sciences, Beijing 100012, China
}

Received 13 March 2006; revised 6 April 2006; accepted 9 May 2006

\begin{abstract}
An investigation of gaseous elemental mercury concentration in atmosphere was conducted at Beijing and Guangzhou urban, Yangtze Delta regional sites and China Global Atmosphere Watch Baseline Observatory (CGAWBO) in Mt. Waliguan of remote continental area of China. High temporal resolved data were obtained using automated mercury analyzer RA-915 ${ }^{+}$. Results showed that the overall hourly mean $\mathrm{Hg}^{0}$ concentrations in Mt. Waliguan were $1.7 \pm 1.1 \mathrm{ng} / \mathrm{m}^{3}$ in summer and $0.6 \pm 0.08 \mathrm{ng} / \mathrm{m}^{3}$ in winter. The concentration in Yangtze Delta regional site was $5.4 \pm 4.1 \mathrm{ng} / \mathrm{m}^{3}$, which was much higher than those in Waliguan continental background area and also higher than that found in North America and Europe rural areas. In Beijing urban area the overall hourly mean $\mathrm{Hg}^{\circ}$ concentrations were $8.3 \pm 3.6 \mathrm{ng} / \mathrm{m}^{3}$ in winter, $6.5 \pm 5.2 \mathrm{ng} / \mathrm{m}^{3}$ in spring, $4.9 \pm 3.3 \mathrm{ng} / \mathrm{m}^{3}$ in summer, and $6.7 \pm 3.5 \mathrm{ng} / \mathrm{m}^{3}$ in autumn, respectively, and the concentration was $13.5 \pm 7.1 \mathrm{ng} / \mathrm{m}^{3}$ in Guangzhou site. The mean concentration reached the lowest value at 14:00 and the highest at 02:00 or 20:00 in all monitoring campaigns in Beijing and Guangzhou urban areas, which contrasted with the results measured in Yangtze Delta regional site and Mt. Waliguan. The features of concentration and diurnal variation of $\mathrm{Hg}^{0}$ in Beijing and Guangzhou implied the importance of local anthropogenic sources in contributing to the high $\mathrm{Hg}^{(0}$ concentration in urban areas of China. Contrary seasonal variation patterns of $\mathrm{Hg}^{0}$ concentration were found between urban and remote sites. In Beijing the highest $\mathrm{Hg}^{0}$ concentration was in winter and the lowest in summer, while in Mt. Waliguan the $\mathrm{Hg}^{0}$ concentration in summer was higher than that in winter. These indicated that different processes and factors controlled $\mathrm{Hg}^{0}$ concentration in urban, regional and remote areas.
\end{abstract}

Key words: gaseous elemental mercury; urban/remote sites; monitoring

\section{Introduction}

Mercury exists in the atmosphere predominant in its elemental gaseous form $\left(\mathrm{Hg}^{\circ}\right)$, because it is not very watersoluble and is relatively unreative (Hedgecock and Pirrone, 2001 ). $\mathrm{Hg}^{0}$ has approximately one year residence time, so it is possible for $\mathrm{Hg}^{\circ}$ to undergo a long distance transportation (Schroeder and Munthe, 1998; Lindqvist et al., 1991). The global mercury concentrations increased to a peak in the $1980 \mathrm{~s}$, then decreased to a minimum around 1996 , then the concentrations of $\mathrm{Hg}^{\circ}$ have been nearly constant (Slemr and Scheel, 1998). Global total atmospheric emission of mercury from anthropogenic sources in 1995 was $2143.1 \mathrm{t}$, approximately $56 \%$ of the total from Asia (Pacyna and Pacyna, 2002; Pacyna et al., 2003). According to the results by Hylander (2001), anthropogenic emissions of mercury still increase in Asia because of coal-use increasing and industrialization. Preliminary estimates for the export of gas-phase mercury from China are approximately $150 \mathrm{t} / \mathrm{a}$

Project supported by the National Basic Research Program (973) of China (No. 2003CB415003); the Pilot Project of Knowledge innovation Program of the Chinese Academy of Sciences (No. KZCX3-SW-443) and the National Natural Science Foundation of China (No. 40473055). *Corresponding author. E-mail: zhangxsh@rcees.ac.cn. from biomass/bio-fuel combustion, and approximately 600 t/a from industry, mostly from coal combustion (Friedli $e t$ al., 2004).

Abundant data have been obtained after long-term monitoring for characterizing the temporal distribution of total gaseous mercury in the atmosphere in many regions of Europe and North America, while data of other regions are less available. Recent measurements of atmospheric gaseous mercury conducted in Seoul, Korea (Kim and Kim, 2000, 2001) and in Guiyang, China (Feng et al., 2004) have shown that the mercury concentration in urban air is elevated comparing to that in the regions of Europe, North America and the global background area. China is believed to be a country of increasing atmospheric mercury emission (Hylander, 2001). However, only a few measurements of mercury in ambient air of China have been conducted. Great efforts are needed for more data to be able to describe and understand the temporal and spatial distribution characters of gaseous mercury in China. In particular, there is no literature related with atmospheric mercury in background area in China, whereas much information has been reported on background area in Europe and North America. In this paper, we presented the results 
of gaseous elemental mercury concentration in atmosphere in the urban. suburban, regional and remote continental areas of China.

\section{Experimental}

\subsection{Site description}

Field measurements for gaseous elemental mercury were conducted in four locations in China: Beijing, Guangzhou urban, Yangtze Delta regional sites and China Global Atmos shere Watch Baseline Observatory (CGAW$\mathrm{BO}$ ) located in remote continental area of China. Beijing and Guangzhou represent northern and southern megacities, and bcth of them can be regarded as seriously anthropogenic polluted cities. Beijing site was located at Research Center for Eco-Environmental Sciences, between the fourth and fifth ring road in the northwest of Beijing urban area. G langzhou site was set at the city meteorological observatory in Baiyun District, northern the city. Yangtze Delte regional site was located at Shuangqiao farm $\left(30^{\circ} 50^{\prime} \mathrm{N}, 120^{\circ} 42^{\prime} \mathrm{E}\right)$ in Jiaxing County, which is in Zhejiang Province and tens kilometers away from cities. The dominant ropping system of the farm was the rotation of winter wheat-rice. CGAWBO is an official of World Meteorological Organization (WMO) Global Atmospheric Watch (GAW) station, a unique continental baseline observatory in Eurisia. It located on the top of Mt. Waliguan that lies in the northeast part of Qinghai-Tibet plateau in Gonghe County, Qinghai Province, with altitude of $3816 \mathrm{~m}$. There is generally pristine area with arid and semi-arid grassland. The population density is less than 6 persons $/ \mathrm{km}^{2}$ and the station is relatively isolated from industrial and sopulation centers.

\subsection{Measuremients}

Measureme its of gaseous elemental mercury were conducted with RA-915 ${ }^{+}$Mercury Analyzer (Lumex Ltd, St-Petersburg. Russia), which is based on the principle of Zeeman Atorric Absorption Spectrometry and High Frequency Modulated Light Polarizatiodtaien (ZAAS-HFM). RA-915 Zeeman Analyzer provides continuous determination of $\mathrm{Hg}^{\prime}$ concentration. The detection limit (DL) is $1.5-2.0 \mathrm{ng} / \mathrm{m}^{3}$ with the response time being $1 \mathrm{~s}$ and 0.3 $\mathrm{ng} / \mathrm{m}^{3}$ with the response time of $30 \mathrm{~s}$ during permanent air pumping through the multi-path analytical cell of the RA $-915^{+}$at a rate of $25 \mathrm{~L} / \mathrm{min}$. The RA $-915^{+}$mercury analyzer is equipped with a built-in mercury permeation source, and frior to monitoring the analyzer needs to calibrate in test mode for assurance the reliability and accuracy of m sasurement data. A more description of our monitoring method and its quality assurance and quality control (QA-()C) has been shown elsewhere (Sholupov and Ganeyer, 1995: Ganeyer et al., 1995; Śpiric and Mashyanov, 2000; Sholupov et al., 2004).

In this study, real-time measurements of elemental gaseous mercury concentration were conducted in off-hand mode and the response time was set 1 min. One-hour continuous measurements were set to start at 02:00, 08:00,
14:00 and 20:00 in a monitoring day in all campaigns. Real time and hourly average $\mathrm{Hg}^{0}$ concentrations were then obtained and analyzed.

Four monitoring campaigns (including 10-20 monitoring days for each) in Beijing were performed in January, April, July and October in 2005, which represented winter, spring, summer and autumn respectively. Two monitoring campaigns were conducted at Mt. Waliguan in summer (two weeks in August) and winter (two weeks in December) and one campaign at Guangzhou in winter (two weeks in January) and Yangtze Delta regional site in autumn (two weeks in September) respectively in 2005.

\section{Results and discussion}

\subsection{Real time $\mathrm{Hg}^{0}$ concentrations}

The results of typical 1 -h real time monitoring ( $1 \mathrm{~min}$ response time) of $\mathrm{Hg}^{0}$ concentration are shown in Fig.1. It can be seen from Fig. 1a that very low $\mathrm{Hg}^{0}$ concentration was almost unchanged with time; this was only observed in Mt. Waliguan in winter. Usually most winter air flow come to Mt. Waliguan from the western plateau region with remote background features. Low concentration with a little fluctuation of $\mathrm{Hg}^{0}$ showed in Fig. $1 \mathrm{c}$ was monitored not only in Mt. Waliguan in summer cases but also in Beijing urban area in winter cases. In summer Mt. Waliguan air masses often come from eastern part of China. But in Beijing there usually gets clean air in winter for a period when strong cold wind passed. Fig.ld shows high value and relatively large fluctuation of $\mathrm{Hg}^{\circ}$ concentration in 1-h monitoring period. It was the cases of serious air pollution observed in heating season of Beijing and in Guangzhou winter. Fig. Ib represents the others of the cases observed in Beijing and in Yangtze Delta site, in which local and regional emission of mercury disturbed more or less the $\mathrm{Hg}^{0}$ concentration in the air.

\subsection{Remote continental background $\mathrm{Hg}^{0}$ concentra- tions}

Fig. 2 shows the hourly mean $\mathrm{Hg}^{0}$ concentrations at 02:00, 08:00, 14:00 and 20:00 and the overall aver-

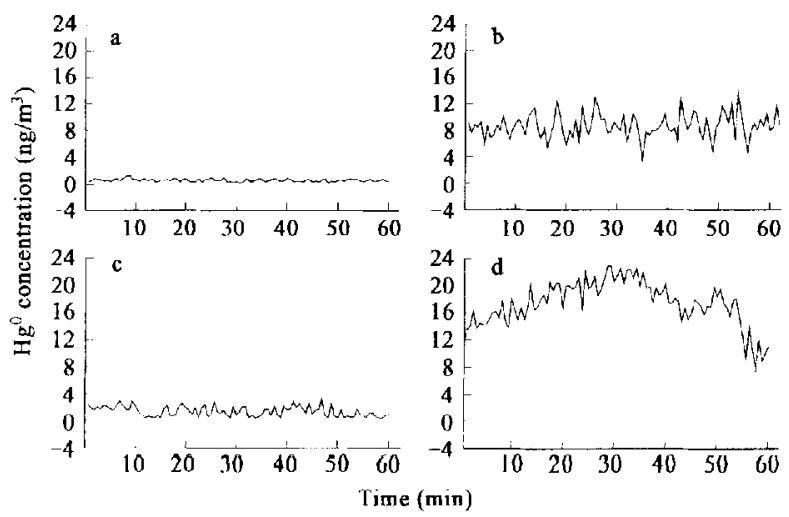

Fig. I Typical cases of real time $\mathrm{Hg}^{0}$ concentration during $\mathrm{I}$-h monitoring at Mt. Waliguan site in winter (a), Beijing urban site in spring, summer and autumn seasons and Yangtze Delta site (b), Mt. Waliguan site in summer and Beijing urban site in winter (c), and Beijing site in heating season and Guangzhou urban site in winter (d). 

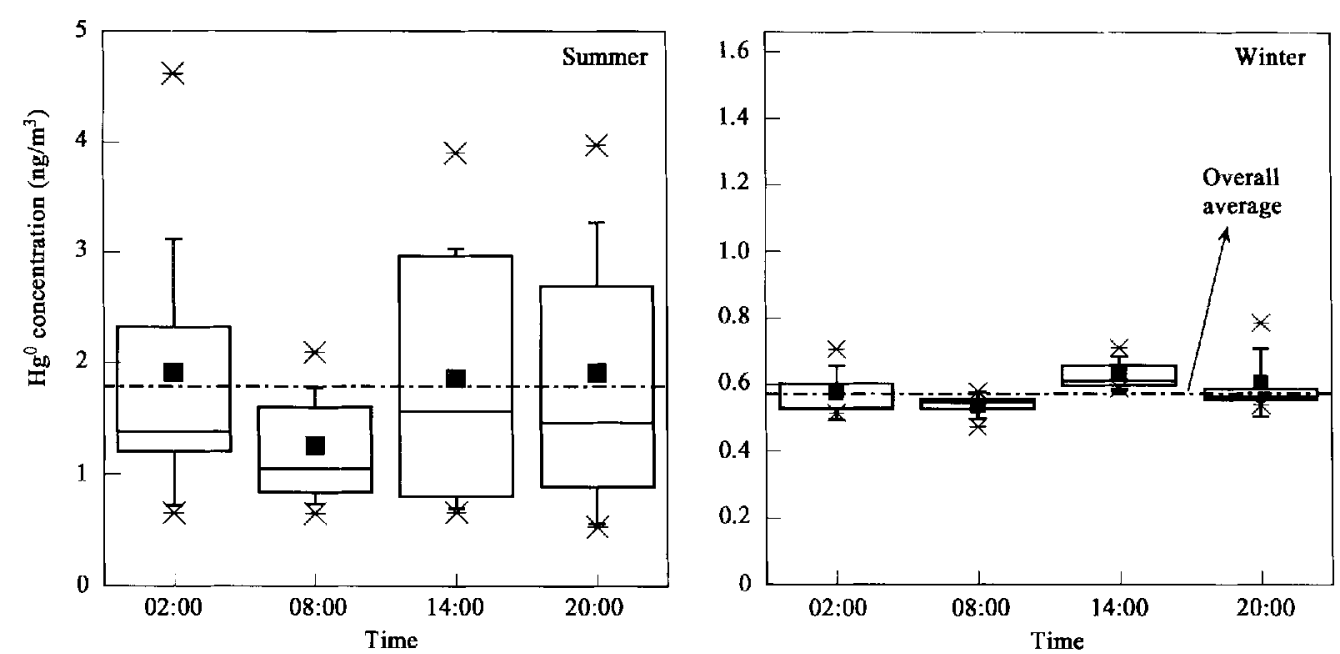

Fig. 2 Hourly mean $\mathrm{Hg}^{0}$ concentrations at 02:00, 08:00, 14:00 and 20:00 during monitoring campaign in Mt. Waliguan Observatory. The asterisks represent maximum and minimum, the bar is $\pm S D$; the box plots are the 25th and 75th percentiles, respectively; the dot is mean; and the line is median. The same legend in the followings.

age concentration during each monitoring campaign in Mt. Waliguan Observatory. The overall mean $\mathrm{Hg}^{0}$ concentrations were $1.7 \pm 1.1 \mathrm{ng} / \mathrm{m}^{3}$ in summer monitoring campaign and $0.6 \pm 0.08 \mathrm{ng} / \mathrm{m}^{3}$ in winter, which were comparable with the background levels of total gaseous mercury (TGM) in North hemisphere $\left(1.5-2.0 \mathrm{ng} / \mathrm{m}^{3}\right)$ and in South hemisphere (1.1-1.4 ng/ $/ \mathrm{m}^{3}$ ) (Ebinghaus et al., 2002; Schroeder, 2001; Lamborg et al., 2002). The lower mean concentration of $\mathrm{Hg}^{0}$ in winter than that in summer could due to the lower air temperature and lesser solar radiation in winter season. This seasonal variation was also consistent with those studies in North America and Europe finding that peak levels of $\mathrm{Hg}^{0}$ were in spring or summer and reached the lowest values in winter (Slemer and Scheel, 1998). In summer Mt. Waliguan air masses often come from eastern part of China which suggested that long range transportation from eastern China influence the $\mathrm{Hg}^{0}$ concentration. From Fig.2, a slightly diurnal variation of $\mathrm{Hg}^{0}$ concentration can be found in Mt. Waliguan with the lowest $\mathrm{Hg}^{0}$ concentration at 08:00 both in summer and winter. The diurnal variation amplitude in summer was larger than that in winter.

\subsection{Regional background $\mathrm{Hg}^{0}$ concentrations}

Fig. 3 shows the hourly mean $\mathrm{Hg}^{0}$ concentrations at 02:00, 08:00, 14:00 and 20:00 and the overall average concentration during each monitoring campaign at Yangtze Delta regional site. The overall mean $\mathrm{Hg}^{0}$ concentrations were $5.4 \pm 4.1 \mathrm{ng} / \mathrm{m}^{3}$ in the monitoring campaign, which were higher the concentrations $\left(1.32-1.83 \mathrm{ng} / \mathrm{m}^{3}\right)$ in Canada rural sites (CAMNet) (Kellerhals et al., 2003) and the concentrations $\left(1.63 \pm 0.35 \mathrm{ng} / \mathrm{m}^{3}\right)$ in summer season at Poland rural site (Zielonka et al., 2005). Contrary to Mt. Waliguan, there was clearly diumal variation of $\mathrm{Hg}^{0}$ concentration in Yangtze Delta regional site, which exhibited a daytime dominant pattern of $\mathrm{Hg}^{0}$ concentration during monitoring period. The $\mathrm{Hg}^{0}$ concentration increased from midnight and reached the highest peak value at noon and then decreased. This was consistent with those measurements in CAMNet (Kellerhals et al., 2003) and could be explained to re-emission of mercury from surface soil of farmland for high temperature and solar radiation, or the transportation from the emission sources.

\section{$2.4 \mathrm{Hg}^{\mathbf{0}}$ concentration in urban areas}

Figs. 4 and 5 show the hourly mean $\mathrm{Hg}^{0}$ concentrations at 02:00,08:00, 14:00 and 20:00 and the overall average concentration during each monitoring campaign at sites in Beijing and Guangzhou urban areas.

The overall mean $\mathrm{Hg}^{0}$ concentration in Beijing reached the lowest $4.9 \pm 3.3 \mathrm{ng} / \mathrm{m}^{3}$ in summer, the highest $8.3 \pm 3.6$ $\mathrm{ng} / \mathrm{m}^{3}$ in winter, $6.5 \pm 5.2 \mathrm{ng} / \mathrm{m}^{3}$ in spring, and $6.7 \pm 3.5$ $\mathrm{ng} / \mathrm{m}^{3}$ in autumn (Fig.4). These concentrations were much higher than those measured in MT. Waliguan of remote continental background area, and slightly higher than that in Yangtze Delta regional background area. The highest $\mathrm{Hg}^{0}$ concentration in winter was a little lower than the concentration $\left(10.71 \mathrm{ng} / \mathrm{m}^{3}\right)$ reported by Liu et al. (2002) at the same monitoring site and the concentration (10.54 $\mathrm{ng} / \mathrm{m}^{3}$ ) in Guiyang (Feng et al., 2004). The seasonal variation of $\mathrm{Hg}^{0}$ concentrations in Beijing was consistent to that in Seoul of Korea (Kim and Kim 2001), but contrary to that in Mt. Waliguan. A high overall average $\mathrm{Hg}^{0}$ concentration $13.5 \pm 7.1 \mathrm{ng} / \mathrm{m}^{3}$ was also found in Guangzhou (Fig.5) indicating that strong local/regional anthropogenic sources

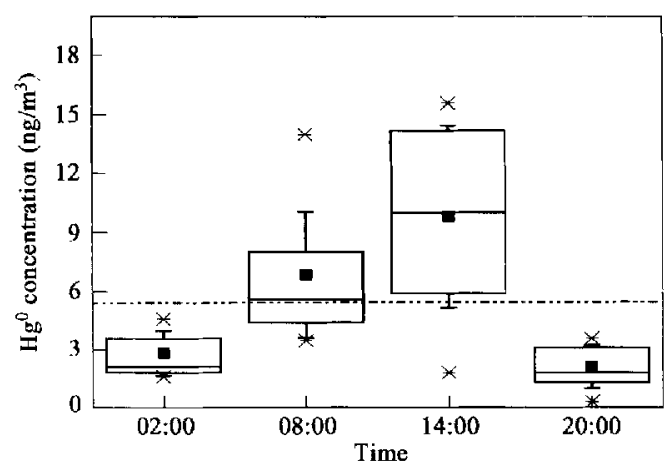

Fig. 3 Hourly mean $\mathrm{Hg}^{0}$ concentrations at 02:00, 08:00, 14:00 and 20:00 during monitoring campaign in Yangtze Delta regional site. 

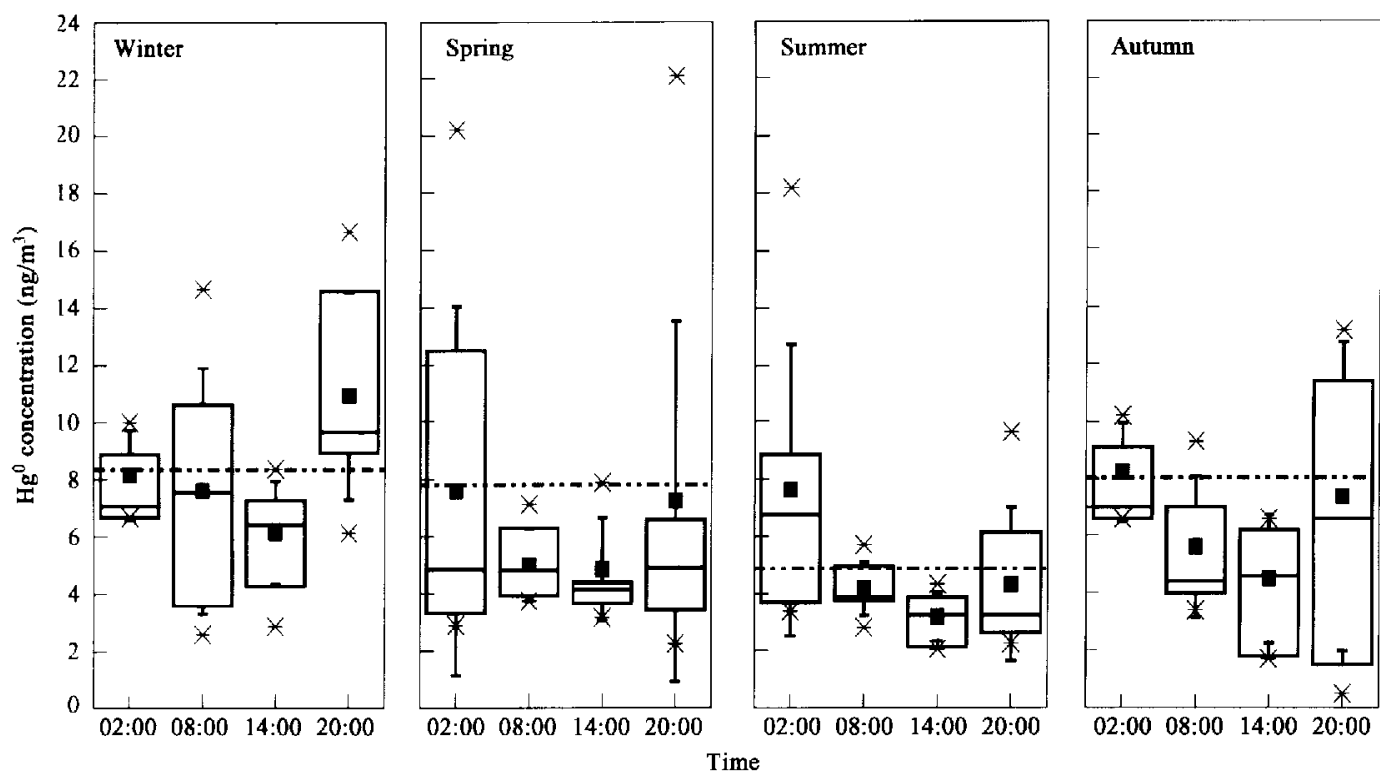

Fig 4 Hourly mean $\mathrm{Hg}^{0}$ concentrations at 02:00,08:00, 14:00 and 20:00 during monitoring campaign at Beijing urban site.

of mercury contributing to airborne $\mathrm{Hg}^{0}$ not only in Beijing but also in Guangzhou.

Diurnal variation of $\mathrm{Hg}^{0}$ concentration can be seen in Figs. 4 and 5. It is obvious that the mean concentration reached the lowest value at $14: 00$ and the highest at 02:00 or 20:00 in all monitoring campaigns in Beijing and Guangzhou cities. These results contrasted with what's measured in Yangtze Delta regional site but were comparable to those reported of Lee et al. (1998) and Kim and Kim (2001). 'The features of diurnal variation in Beijing and Guangzhou could indicate the importance of local emission of $\mathrm{Hg}^{0}$ in the urban areas. During nighttime local emission of $\mathrm{Hg}^{0}$ accumulated in shallow boundary layer but during the daytime the concentrations of $\mathrm{Hg}^{0}$ were

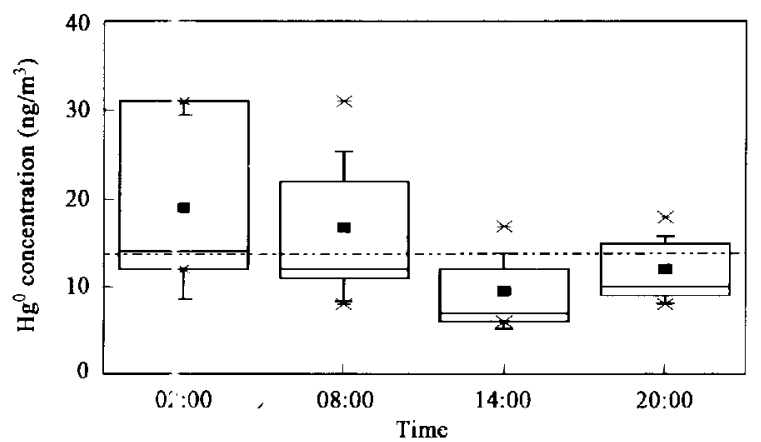

Fig. 5 Hourly me in $\mathrm{Hg}^{0}$ concentrations at 02:00, 08:00, 14:00 and 20:00 during monitorin! sampaign at Guangzhou urban site. diluted by thermal mixing which results in the increases of the boundary-layer depth.

Summary of overall hourly average concentrations of $\mathrm{Hg}^{0}$ at all sites during monitoring campaigns are given in Table 1.

\section{Conclusions}

The investigation of gaseous elemental mercury concentration in atmosphere conducted at Beijing and Guangzhou urban, Yangtze Delta regional sites and China Global Atmosphere Watch Baseline Observatory (CGAWBO) in Mt. Waliguan showed that the $\mathrm{Hg}^{0}$ concentrations in continental background area, Mt.Waliguan, were comparable to that reported in global background area. However the concentrations in urban and regional sites were higher than what found in corresponding areas of Europe and North America. The $\mathrm{Hg}^{0}$ concentrations in urban area were higher than those in regional background area and much higher than those in remote continental background in this study.

The features of concentration and diurnal variation of $\mathrm{Hg}^{\mathrm{O}}$ in urban areas indicated the importance of local anthropogenic sources in contributing to the high $\mathrm{Hg}^{0}$ concentration in urban areas of China. Contrary seasonal variation patterns of $\mathrm{Hg}^{0}$ concentration were found between remote continental and urban sites. These indicated

Table 1 Summary of $\mathrm{Hg}^{\mathbf{0}}$ concentrations at all sites during monitoring campaigns

\begin{tabular}{|c|c|c|c|c|c|}
\hline Site & Site type & Month & Mean $\left(\mathrm{ng} / \mathrm{m}^{3}\right)$ & Minimum $\left(\mathrm{ng} / \mathrm{m}^{3}\right)$ & Maximum $\left(n g / m^{3}\right)$ \\
\hline \multirow[t]{2}{*}{ Waliguan } & \multirow[t]{2}{*}{ Remote continental } & August & $1.7 \pm 1.1$ & 0.5 & 4.6 \\
\hline & & December & $0.6+0.08$ & 0.5 & 0.8 \\
\hline Shuangqiao farm & Yangtze Delta regional & September & $5.4 \pm 4.1$ & 0.6 & 14.4 \\
\hline Guangzhou & Urban & January & $13.5 \pm 7.1$ & 6 & 31 \\
\hline \multirow[t]{4}{*}{ Beijing } & \multirow[t]{4}{*}{ Urban } & January & $8.3 \pm 3.6$ & 2.6 & 14.7 \\
\hline & & April & $6.5 \pm 5.2$ & 2.3 & 29.1 \\
\hline & & July & $4.9 \pm 3.3$ & 2 & 18.2 \\
\hline & & October & $6.7 \pm 3.5$ & 3.4 & 13.2 \\
\hline
\end{tabular}


that different processes and factors controlled $\mathrm{Hg}^{0}$ concentration in urban, regional and remote areas.

Acknowledgements: The authors are grateful to Mr. Deli Ge-Er and Ji Jun in China Global Atmosphere Watch Baseline Observatory (CGAWBO) for their help in this work.

\section{References}

Ebinghaus R, Kock H, Temme C et al., 2002. Antarctic springtime depletion of atmospheric mercury[J]. Environ Sci Technol, 36: 1238-1244.

Feng X, Shang L, Wang S et al., 2004. Temporal variation of total gaseous mercury in the air of Guiyang, China[J]. Geophysical Research, 109, D03303: doi: 10. 1029/2003JD00419.

Friedli H, Radke L, Prescott R, 2004. Mercury in the atmosphere around Japan, Korea, and China as observed during the 2001 ACE-Asia field campaign: Measurements, diatributons, soures, and implications[J]. Geophysical Research 109, D19S25: dio: 10.1029/2003JD004244.

Ganeyev A, Sholupov S, Slyadnev M, 1995. Zeeman modulation polarization spectrometry as a version of atomic-absorption analysis: potential and limitations[J]. Anal Chem, 51: 788795.

Hedgecock I, Pirrone N, 2001. Mercury and photochemistry in the marine boundary layer-modeling studies suggest the in situ production of reactive gas phase mercury[J]. Atmospheric Environment, 35: 3055-3062.

Hylander L, 2001. Global mercury pollution and its expected decrease after a mercury trade ban[J]. Water Air and Soil Pollution, 125: 331-344.

Kellerhals M, Beauchamp S, Belzer W et al., 2003. Temporal and spatial variability of total gaseous mercury in Canada: results from the Canadian Atmospheric Mercury Measurement Network (CAMNet) $[\mathrm{J}]$. Atmospheric Environment, 37: 1003-1011.

Kim K, Kim M, 2000. The effects of anthropogenic sources on temporal distribution characteristics og total gaseous mercury[J]. Atmospheric Environment, 34: 3331-3341.

$\operatorname{Kim} \mathrm{K}, \mathrm{Kim} \mathrm{M}, 2001$. The temporal distribution characteristics of total gaseous mercury at an urban monitoring site in Seoul during 1999-2000[J]. Atmospheric Environment, 35: 4253
$-4263$.

Lamborg C, Fitzgerald W, Donnell J et al., 2002. A non-steadystate compartmental model of global-scale mercury biogeo chemistry with interhemispheric atmospheric gradients[J]. Geochim Cosmochim Acta, 66: 1105-1118.

Lee D, Dollard G, Pepler S, 1998. Gas-phase mercury in the atmoshpere of the United Kingdom[J]. Atmospheric Environment, 32: 855-864.

Lindqvist O, Johansson K, Aastrup M et al., 1991. Mercury in Swedish environment: recent research on causes, consequences and corrective methods[J]. Water Air and Soil Polltion, 55: 23-32.

Liu S, Nadim F, Perkins C et al., 2002. Atmospheric mercury monitoring survey in Beijing, China[J]. Chemosphere, 48: 97-107.

Pacyna E, Pacyna J, 2002. Global emission of mercury from anthropogenic sources in 1995[J]. Water Air and Soil Pollution, 137: 149-165.

Pacyna J, Pacyna E, Steenhuisen F et al., 2003. Global mercury emissions $[\mathrm{C}]$. Presented at Long Range Transport Workshop, Ann Arbor, MI, September 2003.

Schroeder W, Munthe J, 1998. Atmospheric mercury-an overview[J]. Atmospheric Environment, 32: 809-822.

Schroeder W, 2001. Mercury rising or falling?[C]. Abstracts of the 6th International Conference on Mercury as a Global Pollutant, October, Minamata, Japan. 15-19.

Sholupov S, Ganeyev A, 1995. Zeeman absorption spectrometry using high frequency modulated light polarization $[\mathrm{J}]$. Spectrochim Acta Part B: Atom Spectrosc, 50B: 1227-1233.

Sholupov S, Pogarev S, Mashyanov N et al., 2004. Zeeman atomic absorption spectrometer RA $-915^{+}$for direct determination of mercury in air and complex matrix samples[J]. Fuel Processing Technology, 85: 473-485.

Slemer F, Scheel H, 1998. Trend of atmospheric mecury concentraions at the summit of the Wank Mountain, southern Germany[J]. Atmospheric Environment, 32: 845-853.

Špiric Z, Mashyanov N, 2000. Mercury measurements in ambient air near natural gas processing facilities $[\mathrm{J}]$. Fresenius Anal Chem, 366: 429-432.

Zielonka U, Hlawiczka S, Fudala J et al., 2005. Seasonal mercury concentrations measured in rural air in Southern Poland Contribution from local and regional coal combustion[J]. Atmospheric Enviroment, 39: 7580-7586. 